\title{
História Oral e a juventude trabalhadora na periferia: limites, pressões e expectativas
}

\author{
Douglas Gonsalves Fávero* \\ Sérgio Paulo Morais ${ }^{* *}$
}

\section{Introdução}

Este artigo apresenta um recorte a partir de pesquisas sobre trabalho e modos de vida no Triângulo Mineiro ${ }^{1}$, executado pelo Grupo de Pesquisa Experiências e Processos Sociais (GPEPS), enfocando jovens trabalhadores de uma ocupaçáo urbana localizada na periferia de Uberlândia (MG). Buscamos demonstrar as dimensóes objetivas e a experiência vivida e pensada em torno das relaçóes de trabalho vivenciadas pelos jovens a partir do contexto de periferia e de ocupação.

Para esse recorte, buscamos, também, demonstrar as potencialidades da História Oral como uma metodologia de pesquisa inserida em uma lógica histórica

Mestre e doutorando em Educação pelo Programa de Pós-Graduação em Educação (PPGED) da Faculdade de Educação (FACED) da Universidade Federal de Uberlândia (UFU), vinculado à linha de pesquisa Trabalho, Sociedade e Educação. Membro do Grupo de Pesquisa Experiências e Processos Sociais (GPEPS). Bolsista da Fundação de Amparo à Pesquisa do Estado de Minas Gerais (FAPEMIG). E-mail: faverodg@ gmail.com.

" Doutor em História pela Pontifícia Universidade Católica de São Paulo (PUC-SP). Professor do Instituto de História (INHIS) e dos programas de pós-graduação em Educação (PPGED/FACED) e em História (PPGH/INHIS) da Universidade Federal de Uberlândia (UFU). Coordenador do Grupo de Pesquisa Experiências e Processos Sociais (GPEPS). E-mail: moraissp@yahoo.com.br.

1 Trata-se das pesquisas: "História Social e História oral: pesquisas sobre trabalho e trabalhadores no Triângulo Mineiro (2000-2016)", com financiamento da Fundação de Amparo à Pesquisa do Estado Minas Gerais (FAPEMIG/APQ-02063-17), e "Ensino Formal e Programa Bolsa Escola Federal: experiências, vivências e interpretações de assistidos na cidade de Uberlândia MG", com financiamento do Conselho Nacional de Desenvolvimento Científico e Tecnológico (CNPq-409878/2018-9). 
(Thompson, 1981, p. 47-61) de produção de conhecimento - que produz um diálogo entre evidências e hipóteses com conceitos teóricos.

A experiência - tanto individual como coletiva - consiste em uma resposta emocional e mental aos processos históricos vividos (Thompson, 1981, p. 15). Desse modo, a experiência é um processo tanto vivido quanto pensado e sentido, de forma que, conforme aponta Raymond Williams, essas duas dimensōes indicam:

(i) o conhecimento reunido a partir de acontecimentos passados, seja pela observação consciente, seja pela consideração e pela reflexão; e (ii) um tipo específico de consciência que pode em alguns contextos ser distinto de 'razão' ou de 'conhecimento'. (Williams, 2007, p. 173).

Nesse sentido, vemos a História Oral como uma possibilidade mediada de captar as experiências, uma vez que as pessoas não narram apenas sobre os fatos, mas também sobre suas interpretaçóes a respeito dos acontecimentos, assim como os significados que atribuem a eles (Portelli, 1996). Dessa forma:

Representações e 'fatos' não existem em esferas isoladas. As representações se utilizam dos fatos e alegam que são fatos; os fatos são reconhecidos e organizados de acordo com as representaçóes; tanto fatos quanto representaçóes convergem na subjetividade dos seres humanos e são envoltos em sua linguagem. Talvez essa interação seja o campo específico da história oral, que é contabilizada como história com fatos reconstruídos, mas também aprende, em sua prática de trabalho de campo dialógico e na confrontação crítica com a alteridade dos narradores, a entender representaçóes. (Portelli, 2006, p. 111).

Assim como qualquer tipo de fonte, não vemos as narrativas como constructos teóricos por si só, ou como representações imediatas da realidade. Pelo contrário, orientados pela lógica histórica (Thompson, 1981), as fontes orais precisam ser interrogadas e inseridas em seu contexto de produção, de forma a compreender o indivíduo não como as "robinsonadas" da economia política (Marx, 2011, p. 39), mas como sujeitos interligados por um conjunto de determinaçóes sociais e históricas.

Nessa direção, o trabalho com a História Oral coloca em outros termos, quando comparado com uma dimensão quantitativa ou estatística, a questão da representatividade social. Dessa forma, a História Oral possibilita uma compreensão do social a partir de duas perspectivas: experiências e possibilidades compartilhadas. Quanto a primeira, E. P. Thompson, ainda que não lide com História Oral, ajuda-nos a entender: 
A filinha de um oleiro costumava comprar costeletas e outras seletas iguarias no açougue dizendo: 'Por favor, senhor, meu pai não se importa com o preço no momento, mas quer boas costeletas, e que sejam macias, por favor, porque ele é oleiro'. No inverno a situação era outra: 'Por favor, senhor, tenho quatro pennies e devo levar algo barato para casa. Meu pai não se importa com o que seja, desde que seja barato. É inverno, e ele está sem trabalho porque é oleiro'. (Thompson, 2012a, p. 226).

Essa menina pode nem sequer ter existido, porém tal biografia extrapola a si mesmo, pois a situação de bons empregos no verão e desemprego no inverno era uma experiência partilhada pelo conjunto dos oleiros do período da Revolução Industrial. Em mesmo sentido, José Sergio de Leite Lopes (1997) consegue captar, por intermédio de entrevistas, rituais em que os trabalhadores se apresentavam para o patrão-coronel da cidade, que decidia sobre as atividades que seriam realizadas a partir da análise das mãos dos trabalhadores. Esse ritual de "dominação industrial" não se encontrava em nenhum tipo de fonte escrita, porém era relatado até mesmo por quem não o viveu.

Por outro lado, a representatividade também se justifica pelas possibilidades postas e compartilhadas. Nesse caso, o caráter representativo de uma entrevista se dá pela sua exceção e singularidade. Portelli $(1996$, p. 8) indica essa relação a partir da crítica a uma possível escravidão branda nos Estados Unidos da América, já que os escravos eram chicoteados 0,7 vezes por ano. Porém, para o autor, um escravo chicoteado pode esclarecer mais a sociedade escravista que os outros 99 que não foram. Dessa forma:

Portanto, a palavra-chave aqui é possibilidade. No plano textual, a representatividade das fontes orais e das memórias se mede pela capacidade de abrir e delinear o campo das possibilidades expressivas. No plano dos conteúdos, mede-se não tanto pela reconstrução da experiência concreta, mas pelo delinear da esfera subjetiva da experiência imaginável: não tanto o que acontece materialmente com as pessoas, mas o que as pessoas sabem ou imaginam que possa suceder. E é o complexo horizonte das possibilidades o que constrói o âmbito de uma subjetividade socialmente compartilhada. (Portelli, 1996, p. 7-8, grifos no original).

É nesse sentido que destacamos nas narrativas as vivências e possibilidades compartilhadas, que, no diálogo com outras evidências e constructos teóricos, nos possibilita uma apreensão da experiência social mais ampla de indivíduos e de grupos, assim como do processo social estruturado como um todo.

$\mathrm{O}$ recorte que aqui fizemos segue o fio condutor das relaçóes de trabalho 
vividas e pensadas pelos jovens da ocupação, perpassando por determinaçóes ${ }^{2}$ objetivas e estruturantes da vida social, seguindo para as dimensóes de classe as quais as relaçóes de trabalho estão envolvidas.

\section{O trabalho como estruturante da vida social}

Para além das formulaçôes clássicas, a partir da crítica da economia política e seus desdobramentos com a sociologia do trabalho, buscamos apreender as formas de manifestações que as relaçóes de trabalho contemporâneas adentram na vida dos jovens trabalhadores das periferias de grandes centros urbanos. Isso não implica em uma negação dessa perspectiva teórica, mas de tomá-la como um guia para a apreensão das experiências e do processo estruturado, extrapolando o mundo do trabalho para o mundo dos trabalhadores (Khoury, 2009).

Compreender as relaçóes sociais em uma perspectiva histórica implica em ter como um ponto de partida a produção da vida social, em manifestaçôes particulares da vida concreta. Nessa dimensão, temos as relaçóes de trabalho como centro do processo, produzindo e reproduzindo a vida em sua totalidade, operando como uma espécie de "iluminação universal em que todas as demais cores estão imersas e que as modifica em sua particularidade. É um éter particular que determina o peso específico de toda existência que nele se manifesta" (Marx, 2011, p. 59).

As relaçóes de trabalho e (náo) propriedade ${ }^{3}$ implicam diretamente em um conjunto de relaçóes da vida social, como a de moradia, como afirma Patrícia, ${ }^{4}$ jovem de 20 anos que morava na ocupação com a filha de cinco meses: "[...] vim pra cá pra estudar... aí eu vinha de van, todos os dias e voltava pra lá. Aí, depois eu vim morar direto pra cá quando eu vim trabalhar" (Patrícia, 2015). Em outra perspectiva, partilhada por diversos dos jovens, relata Ernesto, jovem de 22 anos que foi para a ocupação acompanhando os pais:

2 Por determinações, compreendemos as relações, as formas de ser e existir e os aspectos singulares que são historicamente constituintes do objeto pesquisado, que "é dado tanto na realidade como na cabeça" (Marx, 2011, p. 59). As determinações implicam em processos objetivos - ou seja, criados pela ação humana - de fixação de limites e exercícios de pressões. Os primeiros estabelecem o leque de possibilidades para a prática humana, enquanto os segundo pressionam, a partir da formação social, o ser social a agir e a comportar-se de um modo específico (Thompson, 1981, p. 176; Williams, 1979, p. 87-93).

3 Os jovens por nós pesquisados encontram-se na perspectiva de ter na força de trabalho a única propriedade possível, tendo que confrontá-la com o capital, na forma de mercadoria, para garantir a própria sobrevivência, condição típica e essencial da sociedade capitalista (Marx, 2017, p. 242-244).

4 No estudo dos jovens da ocupação, foram realizadas oito entrevistas de História Oral nas primeiras semanas de novembro de 2015 e transcritas em um documento único. As entrevistas foram realizadas 
[Douglas] - E por que vocês vieram pra cá?

[Ernesto] - Na verdade foi mais por causa da condição que a gente estávamos vivendo, né. Porque num tinha... é... muita condição de sobreviver. Porque a cidade é pequena e num tem muito trabalho assim, mas o custo de vida é muito... muito caro, aí tipo... num dá pra gente sobreviver bem assim... de... de... pagar uma escola pros filhos boa, sabe. Aí a gente viemos pra cá. (Ernesto, 2015).

Diferente de Ernesto, que morava à época da entrevista com a família, Patrícia vivia sozinha com a filha, e tinha no trabalho de fiscal de caixa de supermercado a fonte para sustentar a si e a criança e para a construção da casa, a única entre as dos entrevistados que ainda era de madeira. As relaçóes de trabalho e moradia impactavam até mesmo no planejamento familiar, como relata Tito, um jovem pastor que foi para a ocupação com sua esposa, quando tinham consecutivamente 27 e 26 anos:

Eu tenho, que... sete anos que eu tô casado, casei novo, sete anos. A pessoa, assim, quando vê a gente, qual é a primeira coisa que pergunta? Cadê o filho? Ah, porque... Eu falo assim.. não, eu amo tanto meu filho, que eu antes de têlo, eu já quero, já quero... já.. prevenir ele de algumas coisas, quer dizer... eu... é... Como que eu vou ter um filho sem ter um.... o principal, que é um lugar pra você morar? Náo tem um... um... uma base assim, de recursos, às vezes não tem o tempo - filho exige tempo, exige dinheiro, exige muitas coisas. Então o quê? Eu não precisei passar por isso, eu vejo pessoas passarem e falo: eu não quero isso pro meu filho, eu quero ser diferente nesse sentido. (Tito, 2015).

A reprodução do núcleo familiar, envolvia, ainda, a dimensão do trabalho doméstico, que em nenhuma entrevista foi considerado como "trabalho", em virtude de sua dimensão não assalariada. Tais relaçóes, por vezes implicavam em tensóes a partir de certa divisão do trabalho no núcleo familiar, como demonstravam Tito e Ernesto:

na casa dos jovens mediante assinatura de um Termo de Consentimento Livre e Esclarecido (TCLE) para os maiores de dezoito anos, ou um Termo de Ciência para os menores, acompanhado do TCLE do responsável. Para preservar a identidade dos jovens, todos os nomes utilizados são fictícios. A idade indicada dos jovens é a que eles tinham no momento da entrevista. Por diversas vezes indicamos as perguntas feitas pelo entrevistador, uma vez que ajuda a esclarecer o sentido da narrativa e, pelo caráter de cocriação das fontes orais entre narrador e historiador, a omissão do historiador implica em "uma sutil distorção [...]: o texto dá as respostas sem as questões, dando a impressão que determinado narrador dirá as mesmas coisas, não importando as circunstâncias" (Portelli, 1997, p. 36). 
[Risos] A muié que arruma as coisas. Nós dividimos mais que eu agora tô.... [no caso desempregado]. Ela sempre diz que eu tenho esse... esse defeito, de não ajudar né, em casa. Mas eu tô me... me policiando e tentando melhorar isso aí... agora eu arrumo as vasilhas... vasilhas é comigo [risos]. (Tito, 2015).

[Douglas] - E como que é as relaçóes da casa? As responsabilidades, as tarefas? [Ernesto] - São boas, eu mesmo num... num estou trabalhando, mas eu como te disse antes, eu sou poeta, escrevo, e fico mais escrevendo.

[Douglas] - Você contribui com as tarefas de casa?

[Ernesto] - Não, normalmente não.

[Irmã de Ernesto] ${ }^{5}$ - Pode mentir um pouquinho fio, eu deixo [risos].

[Ernesto] - De vez em quando ajudo [risos]. (Ernesto, 2015).

Tal dimensão naturalizada do trabalho doméstico somente aparecia nas entrevistas após ser tematizado na forma de perguntas. No caso de Tito, a realizaçáo de trabalho doméstico apenas ocorria quando ele estava desempregado (ou sem trabalho assalariado), reproduzindo uma certa subordinação do trabalho doméstico ao assalariado. Paul Willis (1991, p. 180-184) notou de outra forma a reprodução do sistema familiar-patriarcal entre os trabalhadores, uma vez que a subordinação da mulher no contexto doméstico mostrava-se como uma compensação da subordinação e exploraçáo do trabalho manual masculino, relaçóes bastante difundidas na cultura operária por ele analisada.

O conjunto de relações que envolvem trabalho assalariado se ampliam para diversas outras esferas da vida social, para além da moradia e reprodução do núcleo familiar. No tocante à educação formal, percebemos a tensão estabelecida na relação escola-trabalho. No Brasil, a escola parece afastar o estudante trabalhador, ao mesmo tempo que o trabalho afasta o jovem da escola (Sposito, 2004, p. 81). Antônio, jovem de 20 anos, expressava quando entrevistado a tensáo ao narrar o abandono dos estudos no primeiro ano do ensino médio: "Uai... a situação foi ficando difícil, minha mãe tava sozinha né, que ela separou do meu pai, aí ela ficou sozinha. Aí meus irmãos teve que trabaiá pra ajuda ela... aí eu decidi parar né" (Antônio, 2015).

Por outro lado, os jovens que conseguiram concluir o ensino básico não o fizeram sem dificuldades, como mostra a significativa experiência de Tito, relatando sobre seu primeiro emprego:

Foi... meio... legal né [risos]. Foi numa empresa que mexe com equipamento

5 A entrevista com Ernesto foi realizada na casa de sua irmã, também jovem, que acabou acompanhando toda a entrevista. Apesar de sua presença, suas intervençôes foram muito pontuais e em um certo tom de piada, como esta relatada acima. 
de proteção individual, EPI, fabrica EPI. [...] Estudava a noite e trabalhava de dia. Eu lembro que eu chegava em casa 7 h15 pra tá na escola 7 h30. Quer dizer, eu perdia... perdia a primeira aula e lembro que esse ano, que eu tava cursando o terceiro ano do ensino médio, eu fiquei devendo duas matérias, por quê? [...] porque era sempre o primeiro e o último horário. $\mathrm{O}$ primeiro eu não tinha chegado e no último eu já tava dormindo [risos]... então... é bastante cansativo... e... e... um trabalho industrial... e eu pegava oito ônibus por dia, quatro pra ir e quatro pra voltar. Então você imagina, eu acordava quatro horas da manhã... foi bastante cansativo, foi puxado com força. (Tito, 2015).

Naturalmente, o trabalho não é a única causa da interrupção dos estudos. Nesse sentido, encontramos outras situaçóes, como a gravidez, para as mulheres e, de certa maneira, para os homens, uma vez que necessariamente envolve a necessidade de trabalho para a manutenção do novo núcleo familiar. Encontramos, também, outras situações, como Rosa, jovem que à época da entrevista tinha 27 anos e estava grávida de oito meses, que viveu o extremo da vida em condiçáo de rua, de dependência química e da prisão.

As relaçóes de trabalho também mediam de maneira íntima a sociabilidade juvenil. Ter uma renda constante possibilita aos jovens uma certa autonomia em relação ao núcleo familiar de origem, possibilitando acesso a bens de consumo e a lugares e espaços da cidade. No entanto, e ao mesmo tempo, o trabalho impóe limites para as relaçóes de sociabilidade, fazendo diminuir o tempo livre e de lazer e impondo responsabilidades, propiciando aos jovens a vida em um "mundo adulto", sobretudo quando ligado à reproduçáo do próprio núcleo familiar (Dayrell, 2007). Nessa perspectiva, o relato de Eduardo, jovem que à época da entrevista tinha 15 anos e morava com a mãe e três irmãos, foi bastante significativo:

[Eduardo] - Eu trabalhava num [lanchonete]... de chapeiro.

[Douglas] - Mas era registrado?

[Eduardo] - Não.

[Douglas] - E como que era?

[Eduardo] - Era meio ruim, né! Porque eu trabaiava seis hora. Entrava lá seis hora, saia de lá uma hora da manhã, vinha em casa e acordava seis hora da manhã pra ir pra escola, chegava da escola, arruma a casa, lavava a louça... era correria pra mim.

[Douglas] - E você gostava?

[Eduardo] - Ah... [...] Gostava... porque final de semana eu podia ficar de boa, ir pros lugar né... pro shopping, assistir um filme. É... pra mim era bom. (Eduardo, 2015). 
O trabalho contribui, ainda, na estruturação das relações afetivas e de amizades entre os jovens, uma vez que "[...] nós temos amizade por fora do trabalho também né. De vez em quando nós sai, vai nos bares, ou vai no shopping, nós temos relação por fora também" (Patrícia, 2015). Ou também, quando se confunde as próprias relações de trabalho e amizade: "amigos né... quando nóis trabalha... mais... é só os amigo memo... conheço faz muito tempo, e nóis... de vez em quando nóis encontra ai. [...] nóis faz um churrasquinho... faz... a gente bebe uma cervejinha, fica de boa" (Antônio, 2015).

Tanto no processo de sociabilidade, quanto no acesso a bens culturais e na própria cidade, as relaçóes de trabalho são intrinsicamente ligadas às pressốes de ter ou não dinheiro. A dimensão do dinheiro é uma preocupação constante na vida desses jovens, por conta da reprodução do núcleo familiar, do consumo pessoal e da manutenção de um estilo de vida:

[Douglas] - É... no seu dia a dia, como você costuma gerenciar seu dinheiro? [Eduardo] - É... gastando muito [risos]. É... a maioria... eu compro um negócio aí, pra mim comer a tarde... vou pro centro comprar roupa... isso. [Douglas] - Você costuma comprar bastante roupas?

[Eduardo] - Mais ou menos. Umas três peças por mês... olha lá né.. se o dinheiro vai dar né.

[Douglas] - E como que você faz para gerenciar seu dinheiro pra comprar essas coisas? Só com os bicos dá? Ou sua mãe te ajuda?

[Eduardo] - Minha mãe ajuda né... meu pai também ajuda na pensão. (Eduardo, 2015).

[Alexandra] - Eu sou uma pessoa viciada em doces [risos]. E roupa também. Eu compro umas roupas aí. Piercing, principalmente [risos] [ela tem dois piercing na boca]. É, acho que é só isso. Ajudo de vez em quando aqui em casa, prá coisas... tipo alimentos assim.

[Douglas] - E você compra as coisas com o dinheiro do seu trabalho? [Alexandra] - Pelo meu trabalho. Antes era pela minha mãe, agora é pelo meu serviço [risos]. (Alexandra, 2015).

Alexandra, entrevistada aos quinze anos, trabalhava em um frigorífico com sua mãe. Em sua narrativa foi possível encontrar o orgulho de sustentar seu próprio consumo. $\mathrm{O}$ estilo, aqui, perpassa a dimensão do consumo em sua estreita relação com o dinheiro e o trabalho. Para Dayrell (2001), o estilo implica em um modo de ser jovem, expressando na linguagem e nas gírias, na forma de vestir, nos adereços estéticos e no consumo cultural. Dessa forma, o trabalho, em sua contradição de afirmação e negação da condição juvenil, possibilita um 
consumo que se expressa no estilo.

Paul Willis (1991, p. 31), em outra perspectiva, percebia o estilo tanto como uma forma de resistência de garotos, filhos de trabalhadores braçais, expressando significados particulares em um mercado cultural para os jovens, inferindo uma relação que expressa a contradição entre liberdade e subordinação.

Uma dimensão bastante interessante notada por Willis (1991, p. 164), referente à pressão do dinheiro e do mercado cultural sobre os jovens, foi uma compreensão, ainda que de forma empírica e desarticulada, do caráter abstrato e indiferenciado do trabalho assalariado (Marx, 2017, p. 124), uma vez que, na maioria das vezes, não importa o tipo de trabalho, mas o seu resultado: o salário.

[Douglas] - Você já trabalhou?

[Rosa] - Já.

[Douglas] - Com quê?

[Rosa] - Restaurante, já trabaiei de telemarketing também, manicure, cuidá de cabelo dos outros, vendedora, que eu tenho curso.

[Douglas] - Já fez de tudo né.

[Rosa] - Já.

[Douglas] - E como que foi o seu primeiro emprego? Você lembra?

[Rosa] - O meu? Vender tempero.

[Douglas] - Mas era por conta própria, junto com a família?

[Rosa] - É... Ia lá no CEASA, comprava e... nóis mesmo embalava e vendia.

[Douglas] - E o primeiro como empregada?

[Rosa] - Como empregado? Ah... doméstica e faxina memo. Eu sempre gostei de fazer faxina, porque é um dinheiro mais fácil, rápido... cabou, recebeu... (Rosa, 2015).

[Douglas] - Com que você trabalha?

[Antônio] - No momento eu tô com... fazendo fundação de prédio... Mas minha profissão mesmo é serralheiro... eu virei profissional.

[Douglas] - E você tá registrado?

[Antônio] - Não... Não... Isso aí é só um bico mesmo.

[Douglas] - E você não tá com trabalho de serralheiro?

[Antônio] - Não... Não... Serralheiro não... eu parei, saí do serviço né... um ano e pouco... aí eu fico nesses biquinhos, igual por fora aí e fico aí... [Douglas] - Seu trabalho como serralheiro era registrado? [Antônio] - Era... registrado.

[Douglas] - E como que era? 
[Antônio] - Uai... eu gostava né, que até profissionalizei né... na profissão... fiquei até profissional na profissão, mas foi... nesse caso aí eu tive que sair né. [Douglas] - E você pretende trabalhar como serralheiro de novo?

[Antônio] - Ah... acho que não pretendo mais não. (Antônio, 2015).

As experiências de Rosa e Antônio, que não são exceçóes, indicam relaçóes mais amplas sobre as condiçóes laborais dos jovens nas periferias brasileiras. Essas apontam para uma alta taxa de rotatividade no mercado de trabalho, além de informalidade, precariedade e desemprego (Cardoso, 2012, p. 94). Conforme narra Tito:

[Tito] - A maioria aqui é pessoal da construção civil né... construção civil, pedreiro, é... servente. Essa profissão é uma profissão que não exige muito um curso... exige mais é a prática mesmo. E até quem tem... quem tem... quem tem uma profissáo, não quer estudar mais. Então... eu creio que seja por isso.

[Douglas] - E você é mecânico industrial né?

[Tito] - Sim.

[Douglas] - Onde que você trabalha?

[Tito] - No momento eu to sem trabalhar. Eu to fazendo umas bocas... de... de... [risos] bicos de serralheria, porque eu to sem serviço agora. (Tito, 2015).

As narrativas indicam praticamente uma totalidade dos jovens trabalhadores inseridos em trabalhos manuais ${ }^{6}$ e precários. $\mathrm{O}$ problema não está no trabalho manual em si, mas em sua subordinação ao trabalho intelectual, característica da sociedade capitalista. Nessa subordinação, ainda temos, como característica da formação social dependente brasileira (Fernandes, 2005), uma superexploração da força de trabalho (Marini, 2011, p. 180), implicando em salários mais baixos que o necessário para sobreviver.

Apesar da cidade de Uberlândia fornecer muitos postos de empregos, eles ficam, por sua vez, nas faixas salariais mais baixas, chegando, inclusive, abaixo do nível médio de custo de vida da cidade (Almeida, 2018). Essa desigualdade salarial implica, ainda hoje, na vida dos jovens, pois são alocados nos trabalhos

6 Cabe lembrar que todo trabalho manual necessariamente envolve a dimensão intelectual, conforme demonstra Gramsci (2006b, p. 18, grifo do autor) “[...] de que não existe trabalho puramente físico, e de que mesmo a expressão de Taylor, do 'gorila amestrado', é uma metáfora para indicar um limite numa certa direção: em qualquer trabalho físico, mesmo no mais mecânico e degradado, existe um mínimo de qualificação técnica, isto é, um mínimo de atividade intelectual criadora”. 
manuais com os salários baixos, formando uma parte considerável da camada do chamado precariado. ${ }^{7}$

Desse modo, a experiência juvenil se realiza na periferia em precárias condiçóes de trabalho e renda, influenciando sobre ela as pressóes mais intensas em torno da reprodução do núcleo familiar, da própria sociabilidade e do estilo, tudo mediado pela pressáo do dinheiro, sobretudo pela falta dele.

\section{Expectativas e a moralidade do trabalho}

Ao refletirem sobre a intensidade dos limites e das pressóes em que estão inseridos, as dimensóes morais e valorativas, que expressam um "todo caótico", aparecem em suas representaçóes como sínteses das múltiplas determinaçóes (Marx, 2011, p. 54). As expectativas em torno do trabalho surgem nas narrativas em relação à educação formal, principalmente frente à possibilidade de ascensão social e conquista da moradia a partir dos estudos:

[Douglas] - Qual a importância que os estudos tem pra você??

[Eduardo] - Ah pra mim... a importância é que... que se você estuda né, você pode ir mais além, dá um futuro melhor pra família né. É isso... contribuir em casa. (Eduardo, 2015).

[Douglas] - E você pretende voltar aos estudos?

[Antônio] - Por enquanto não pretendo não né, porque tá meio difícil né. É muito chato também trabaiá de dia e estudar a noite, mas se Deus quiser eu vou voltar ainda.

[Douglas] - Qual a importância que os estudos têm pra você?

[Antônio] - Uai... A importância é que... consegue um serviço melhor né... se tiver uma escolaridade melhor né... tê o ensino fundamental completo né... aí a gente consegue um... serviço melhor... mas, tirando isso... é só uma questão de serviço. (Antônio, 2015).

Ah, os estudos, eles abre as portas né, do futuro. Aí, eu estudei até o ensino

"O precariado é constituído, hoje, por jovens empregados e desempregados do novo mundo do trabalho [...]. Uma de suas características candentes é a invisibilidade social, tendo em vista que estão incorporados em formas atípicas e instáveis de contratação, que disfarçam as relações empregatícias. Além disso, não possuem representação sindical, o que os coloca à margem da camada estável do proletariado organizado." (Alves, 2012, p. 11). 
médio, quando eu fui pra fazer faculdade... aí apertou um pouco por causa do trabalho, eu dei... eu adiantei, aí da outra vez que eu fui fazer, eu engravidei, parei... mas o estudo, ele é muito importante, pra pessoa ter um futuro, poder escolher um trabalho, uma profissão melhor. (Patrícia, 2015).

Tito, por outro lado, expressava uma dimensão contraditória sobre tal relação. Para ele, no Brasil, os estudos não implicavam em uma ascensão social, ao mesmo tempo, pretendia fazer um curso de Psicologia para ter seu próprio negócio e melhorar as próprias condiçóes de trabalho:

[Tito] - É... é... assim... porque pra mim, o estudo... no nosso país eu acho um pouco injusto. Porque aqui... eu costumo dizer sempre: aqui no Brasil pra você ganhar dinheiro, você não... não.... não forma pensando que você vai ganhar dinheiro porque é ilusão. Aqui no Brasil a forma de você ganhar dinheiro é sendo empreendedor. Que nem as pessoas que não tem um... um... não sabe nem fazer uma leitura normal e assim... e a pessoa que é formada ganha bem menos que a pessoa que não sabe nem ler, só porque ele teve a ideia de fazer alguma coisa. Então o Brasil é totalmente injusto. A questão financeira... na questão financeira não compensa muito... se for olhar pelo financeiro, você não forma, você não estuda e não busca conhecimento nenhum, porque o Brasil é injusto acerca disso. Agora... na questáo de conhecimento é tudo. Conhecimento.... você estudar, você procurar... você saber... é... conversar com as pessoas, você saber ter sua ideia acerca dos assuntos que sai, não ficar sendo manipulado por pessoas, por mídia, por... por nada. Conhecimento, pra mim... a meu ver... na questáo de CONHECIMENTO [aumentando a entonação] é... é... é tudo que a pessoa tem que ter. Mas a questão financeira eu creio que é bastante fraco. [Douglas] - Então você acha que os estudos não possibilitam melhores condiçóes de vida?

[Tito] - Na questão financeira?

[Douglas] - Também.... de emprego?

[Tito] - A experiência que eu tive não. Porque, um exemplo... eu trabalhei em mecânico de manutenção e teve muitos engenheiros que trabalhavam comigo e ganhavam menos que eu, qual vai ser a perspectiva que eu vou ter? Vou formar... ah você tem que formar e ser engenheiro. Eu tive patróes que falou: eu pago aí a universidade pra você. Eu falo: pra que que eu vou pagar? Chegar do serviço tarde, cansado... (Tito, 2015).

E mais adiante, em relação a suas expectativas: 
[Tito] -É, eu tenho bastante... eu tenho muitos projetos né, eu tenho muitos sonhos. Assim, eu não sei se... aqui... se... se vai ser aqui, a gente não sabe o que que vai dar isso aqui, mas... eu... Meu sonho, que não é um sonho, é um projeto de vida, eu pretendo... a pouco prazo mesmo assim, concluir meu curso de teologia, que falta poucos... poucas matérias pra terminar lá. Eu não terminei, tranquei, mas vou terminar. Minha esposa, começar a faculdade dela logo, faculdade de... faculdade não, um curso tecnológico de estética, ela quer fazer um curso de estética. Eu, por questão de conhecimento, não questão profissional, eu quero fazer psicologia e... trabalhar pra ganhar dinh... conquistar as coisas né [risos]. ${ }^{8}$ Né... trabalhar, assim... Antes de eu começar qualquer coisa, assim... eu pretendia uma casa, porque assim, eu creio que a base das coisas é você ter um lugar pra você morar, o resto você vai conseguindo. E como, assim, eu tô vendo que é bastante difícil, eu vou ter que pular essa etapa. Se aqui as vezes não der, ou mesmo dando, ou se náo der eu vou ter que pular essa etapa. Eu tenho que partir pra cima, fazer um curso superior. $\mathrm{O}$ meu sonho, assim, na verdade, é abrir um negócio pra mim, foi o que eu disse à você: aqui no Brasil é um país totalmente injusto, porque só o curso superior não te garante nada, não te garante nada, nada, nada. [...]. Eu quero fazer um curso no qual eu seja dono do meu negócio, porque se eu for fazer um curso e trabalhar pros outros eu sei que não vou ganhar dinheiro, eu sei que vou ser um funcionário do mesmo jeito, mesmo não sendo peão, eu vou ser funcionário do mesmo jeito. Então, eu vou fazer um curso, na qual eu seja dono do meu negócio.

[Douglas] - Você acha que ser funcionário é uma coisa ruim?

[Tito] - Funcionários? [risos]... É horrível. Você num... não cresce não. (Tito, 2015).

É curiosa a afirmação de que ser um funcionário não possibilitaria crescimento financeiro. A nosso ver, isso dava indícios de uma certa compreensão das relaçóes de exploraçáo do trabalho, pelo menos em seus contornos de ser empregado. Essa oposição indica uma consciência de classe ${ }^{9}$ em torno dos antagonismos da relação

8 Esse riso de Tito é muito significativo. Em entrevistas de História Oral, essas manifestações - como pausas, silêncios, risos, anedotas, imprecisões, contradições, entre outras - podem vir carregadas de significados. Nesse caso, Tito expressa, a nosso ver de maneira consciente, a contradição que caiu entre não ver nos estudos uma possibilidade de ascensão social e, ao mesmo tempo, buscar no curso superior de Psicologia melhores condições de trabalho e renda.

9 Conforme indica Thompson (2012b, p. 280), a consciência de classe não necessariamente é revolucionária, mas é o que se desenvolve no processo de luta de classes, de modo que "ela não pode ser nem 'verdadeira' nem 'falsa'. É simplesmente o que é". 
capital e trabalho. Isso não nos autoriza a indicar uma relação direta e imediata entre exploração e consciência de classe, porém, encontramos por diversas vezes a consciência da oposição entre um nós e um eles (Hoggart, 1973) em torno do trabalho:

Eu tô procurando, mas na verdade tá mais difícil do que... do que... eles pedem muito, sabe; tem emprego, mas só que eles não escolhem tanto assim, sabe... num... eles fazem, mas pegam poucas pessoas, eles... Eu acho que até uma estratégia que eles fazem, sabe, eles não deixam a pessoa completar o terceiro mês pra num ter... fica só como experiência básica... mas aí, a pessoa perde o direito tudo. (Ernesto, 2015, grifos nossos).

Como informado por Willis (1991, p. 207), é sempre muito difícil compreender de maneira precisa quem são esses eles, por mais que apareçam indicados em diversos momentos a partir das relaçóes de trabalho: seja como na afirmação de Ernesto acima, personificando o eles em torno dos patrôes, ou na narrativa de Rosa, que identifica o eles nos políticos que ficam roubando o dinheiro de quem trabalha, em que o trabalho aparece em sua concepção positiva dominante de dignidade do ser humano ${ }^{10}$ frente à corrupção política:

Eu só quero que aqui saia né, esperança muito grande nossa, de pagar uma água, uma luz, porque... ninguém merece não... tem que viver na dignidade mesmo. Vê se esse povo para de robar e devolve o emprego pra nóis, que agora nóis tá pagando a conta da Petrobras, ${ }^{11}$ nóis num é obrigado não uai, não é... porque direto meu marido... fez cursos, esses trem... maquinista, aí vai, faz uma entrevista e num dá certo aí, entendeu? Então... o desemprego tá demais. (Rosa, 2015, grifo nosso).

A concepçáo moral dominante positiva do trabalho é recomposta pelos moradores da ocupação como um contraponto a sua própria condição de ocupante, assinalada como invasores pela imprensa comercial: "aqui é todo mundo trabalhador”. (De Sordi et al., 2018, p. 219). Nas narrativas dos jovens esse

10 Podemos encontrar a síntese da noção de que o trabalho dignifica o ser humano em Hegel, “[...] enfatizando, sobretudo, seu aspecto positivo; isto é, seu papel na formação do homem." (Vázquez, 2007, p. 74-75). Thompson (2012a, p. 300), por sua vez, demonstra como o metodismo exerceu uma pressão moral no processo de disciplinamento do trabalho, combatendo qualquer aspecto de ócio ou procrastinação por meio da noção dignificante do trabalho.

11 No período das entrevistas, um pouco antes de entrar em pauta na sociedade o pedido de impedimento da presidenta Dilma Rousseff, o grande caso de corrupção noticiado pela imprensa era o da Petrobrás, que inclusive, apareceu por diversas vezes nas entrevistas. 
contraponto é expresso de distintas maneiras, tanto na questão da contraposição da "invasão", mas também, na contraposição da visão de moradores de periferias como criminosos, acentuado ainda mais pela "invasão" de propriedade:

Quer dizer, já te... já tem... preconceito, já é um preconceito com sua... em você... como se você fosse um vagabundo, como se você fosse um ladrão, como se você fosse um miserável, como se você fosse um... POBRE COITADO [dando ênfase]. Todos aqui são pobres coitados. Então tem essa visão do pessoal de fora que olha pra gente... já te... já te... é... jogam uma visão sua que na verdade não é uma visão correta. (Tito, 2015).

Já na contraposição com a noção de criminoso, temos a perspectiva de Antônio, que mesmo após uma experiência de pouco mais de um ano no cárcere, tem no trabalho um contrapontoà pressão policiale comolegitimação de sua ressocialização: "Aí né.... eles fazem a ronda deles né [risos]. Eu fico memo normal né, que eu trabalho... eu tenho... igual eu tenho meu BO [boletim de ocorrência] com eles, mas... eu falo com eles... eu tô trabalhando, eu tô firme" (Antônio, 2015).

Em outro sentido, porém ancorado na mesma concepção positiva sobre o trabalho, encontramos nas narrativas uma contraposição do trabalho com o mundo do crime, da violência e das drogas. Nessa direção, Rosa reestabelecia tal concepçáo moral sobre o trabalho justificando sua entrada no tráfico de drogas por meio da dificuldade de conseguir um emprego formal:

Olha aqui procê vê. Quando eu era mais nova, que eu ficava na rua... eu já morei na rua, num tenho vergonha disso não, mas eu morei. É... tinha um lugar ali, a [entidade assistencial com nome suprimido], você precisava ver, com sol ou chuva, os moradores de rua não faltava, porque... o computador entertia muito a gente, tinha aula de teatro, e a gente assim, sabe aquela, assim... você saber que se você treinar aquilo ali, nó, alguém vai ver, você vai... nossa que importante... Ninguém gostava de faltar. Ninguém... não via ninguém na rua, só depois da tarde, que liberava nóis... nóis já entrava dentro do ônibus pelas porta de trás, que num pagava pra usar o passe pra usar droga, juntava os passe tudo e ia comprar droga. E aí amanhecia, mas no outro dia cedinho tava todo mundo lá, porque lá dava pra tomar banho, tomar café da manhã, tinha muitas atividades lá. E hoje em dia, a gente vai procurar um curso... um curso é maior burocracia. Aí quer que o cidadão vire o que gente? Um emprego, sendo que olha aqui, o dia que eu fui fazer um teste na [empresa de limpeza pública com nome suprimido], eu com esse porte querendo que eu faça flexão, que que tem haver FLEXÃO [bastante brava] com varrer rua, pelo amor de Deus. Eu me senti humilhada, eu não 
fui mais procurar serviço, desde então, eu descrencei, num fui trabalhar mais, preferi vender drogas que foi mais fácil pra mim. Só cheguei no cara e falei: 'ou como que faz?' E ele: 'sério?'. Eu falei: 'sério aí!'. Pronto uai. Agora não, no serviço é uma burocracia, sendo que tem tantas pessoas que tá ali na boa vontade de entrar mesmo, não faltar e não dar banho no patrão, tá... mas é vetado. E muitas coisas que eles ficam fazendo, parece que é pra impedir o trabaiador de trabaiá, desanima qualquer um. É por isso que cada dia que passa o crime tá crescendo mais e as pessoas também, invadindo mais no crime por causa disso. (Rosa, 2015).

Ao narrar uma das experiências no cárcere, Rosa, assim como Antônio, valeu-se da noção ressocializadora do trabalho, reafirmando uma noção positiva e humanizadora do trabalho:

[Rosa] - Não... eu vou falar pra você um negócio, o sistema prisional... é... tramoia também. Porque é um dinheiro que tipo assim, muitos presos que tá lá e já devia ter saído, num sai, fica preso ali dentro; e é um dinheiro que tá roubando da gente também, porque... muitos presos ali dentro já devia ser libertado. Coloca umas pena de 30, 60 anos na pessoa ué, invés de usar o dinheiro desses preso em curso, em ressocialização de preso. Porque eu não concordo que cadeia conserta ninguém não, porque lá dentro, a gente só come e dorme, uai, não faz mais nada. Você tem que fazer uma faxininha, limpar sua cela, pronto e cabou ué... que que você tá aprendendo: limpar cela? Você já sabe limpar sua casa, qualquer um sabe uai. Então, pra mim é coisa que num devia nem ter aí. Porque se evitasse antes, num tinha preso. [Douglas] - Os números mostram que o sistema prisional tem muitos jovens, na verdade é a maioria...

[Rosa] - Não... e uns jovens tudo bonito sô, tudo novo, bom pra trabaiá... ainda. E tipo assim, num tá tão perdido, mas ficando ali dentro vai acabar aí, porque ali que ensina. Ali se a pessoa entra porque roubou um som de carro, sai já... sabendo matar, sai sabendo sequestrar, sabe fazer tudo quando sai de lá. Lá é a escola memo do crime, a cadeia. (Rosa, 2015).

A dimensão humanizadora do trabalho apareceu, para além dos contrapontos morais à visão de criminosos e invasores, como uma fonte de constituição de valores. Ainda que com toda a superexploração e a precarização dos empregos que estão submetidos, as relaçóes de trabalho produzem uma satisfação pessoal que extrapola os limites do consumo e da sociabilidade. Nesse sentido, relata Alexandra sobre como é o seu trabalho em um frigorífico: 
[Douglas] - Você respondeu [no questionário] que trabalha fazendo bicos como auxiliar de produção, como é esse trabalho?

[Alexandra] - É legal, assim... tudo para mim é legal. Eu acho bom trabalhar, é um pouco meio pesado assim, mas eu dou conta.

[Douglas] - Onde que você trabalha?

[Alexandra] - Lá no bairro Brasil, em uma microempresa de abatedouro de frango.

[Douglas] - E o que você costuma fazer lá?

[Alexandra] - Lá eu viro eles. Eles passam num gancho de cabeça pra baixo e eu coloco eles em pé.

[Douglas] - É meio período só né?

[Alexandra] - Meio período. De lá eu vou para a escola.

[Douglas] - Você vai todos os dias?

[Alexandra] - Todos os dias. A patroa não quer que eu falte da escola.

[Douglas] - Tem alguém da sua família que trabalha lá também?

[Alexandra] - Minha mãe.

[Douglas] - Qual a importância que o trabalho tem para você?

[Alexandra] - Eu... pra mim... tipo assim... como é que eu vou falar? [Intervalo com risos]. [...] É como se tivesse uma responsabilidade assim a mais. Tipo você focar naquilo sabendo que você é bom naquilo e pra você aprender cada vez com aquilo que você faz, que você gosta de fazer.

[Douglas] - E você gosta desse trabalho?

[Alexandra] - Eu amo. [risos]. Eu trabalho lá desde 2013. (Alexandra, 2015).

Eu sua pesquisa de doutoramento, Dayrell (2001) encontrou uma relação de não valorização dos jovens em relação ao trabalho. Por outro lado, Willis (1991, p. 133) percebeu uma relação de valorização do trabalho manual que implicava confronto contra certo tipo de trabalho mental, não tão prático. Nesses casos, a cultura operária, expressa em uma cultura contra escolar, promovia um confronto com os conformistas ${ }^{12}$ que acabavam em empregos de escritórios, ou mesmo no confronto contra os professores e a atividade intelectual exercida, indicando desprezos por atividades teóricas que não tivessem uma relação prática imediata.

Paul Willis (1991, p. 210-211) ainda avançou na perspectiva de que a reprodução cultural, junto com o processo ideológico, fazia com que os rapazes acabassem escolhendo os trabalhos manuais, assim como seus pais, mesmo que a educação formal como um todo indicasse profissóes de cunho mais intelectual.

12 Os conformistas eram os conhecidos como "cê-dê-efes", rejeitados e confrontados pelos garotos da cultura contra escolar (Willis, 1991, p. 25-26). 
Em nossa pesquisa, esse processo de reprodução não apareceu fortemente como livre escolha para o trabalho manual, mas sim como as únicas possibilidades concretas.

Perante os limites estreitos imposto pelo trabalho manual e precário, resultantes das relações de classe em que estão inseridos, as expectativas de obterem educação para melhores empregos e condiçóes de vida não se realizam objetivamente, exercendo pressóes que se mostravam como incapacidades individuais dos jovens entrevistados. Isso são traços de uma dimensão perversa do capitalismo dependente, uma vez que a modernização cultural vivida pelo Brasil não foi acompanhada de uma modernização social (Dayrell, 2005, p. 313-314).

\section{Conclusões: a História Oral e a experiência}

Em nosso trabalho foi possível visualizar, mediado pela História Oral, a dimensão ontológica do trabalho sobre o ser social (Marx, 2017, p. 255-261; Engels, 2004). Ainda que a experiência vivida nas relaçóes de trabalho esbarre nas determinaçôes objetivas e de exploração, são narradas e representadas a partir de perspectivas morais e culturais conflitantes, com uma imagem - dominante humanizadora e dignificante.

$\mathrm{O}$ ato de trabalhar possui, então, uma determinação central na vida das pessoas. Desse modo, seguimos compreendendo que "o primeiro princípio do materialismo histórico não é classe, nem a luta de classes, mas a organização da vida material e a reprodução social" (Wood, 2006, p. 99). Essa forma, no contexto apresentado, é objetivada em modos radicais de exploração de trabalho, por parte daqueles que percebem na juventude trabalhadora um promissor elemento de reposição de força de trabalho.

Nas condiçôes indicadas, as relaçóes de trabalho centralizam elementos diversos nas experiências dos jovens que habitam regióes conflituosas, tais como as ocupaçóes urbanas. Nas quais se inter-relacionam exploração do trabalho, vigilância moral, autocensura, conflitos com a polícia e disputas em relação ao centro e a periferia e pelos direitos à cidade.

Entre diversas categorias e grupos, esses trabalhadores são representativos para a compreensão de ideologias atribuídas à ausência de educação formal, à pobreza e a restriçóes à direitos sociais. Por esse veio, o estudo sobre tais trabalhadores e trabalhadoras tende a revelar práticas individuais representativas, que, se por um lado, indicam dinâmicas das condiçóes de vida de pessoas que se encontram subsumidas em atividades que são reconhecidamente de baixa remuneração. Por outro, essas geram avaliaçóes sobre o funcionamento da sociedade e sobre formas 
de viver às margens das riquezas socialmente constituídas.

As perspectivas de classe e as relaçóes precárias e determinantes de trabalho que os jovens estấo envolvidos agem como pressóes e tensóes mais intensas que em outras camadas sociais, de forma que os que vivem nas periferias acabam reféns da informalidade, das altas jornadas e baixos salários que o trabalho manual proporciona no capitalismo dependente.

Ainda que precário e abstrato, as relaçóes de trabalho constituem um aspecto central na geração e vivência de valores e normas morais, sobretudo na concepção positiva e dignificante do trabalho. Tal concepção assume uma força material de crença popular (Gramsci, 2006a, p. 118-119), que dá sentido e organiza a vida cotidiana, ainda que, por vezes, seja apropriado como forma de resistência.

Por fim, visualizamos a História Oral como uma poderosa ferramenta para a apreensão do conjunto das estruturas e determinaçóes que moldam a experiência humana, da mesma forma que possibilita adentrar na intensidade do vivido e nas representatividades do pensado/sentido. Entretanto, tal movimento somente é possível compreendendo a História Oral como uma metodologia que precisa ser subordinada a processos investigativos mais amplos - o que determinará a combinação ou não com outros tipos de evidências -, em diálogo permanente com a teoria.

\section{Referências}

ALMEIDA, Bárbara. Mais de 57\% dos trabalhadores de Uberlândia ganhavam até dois salários mínimos, aponta pesquisa. G1 Triângulo Mineiro, Uberlândia, 1 mai. 2018. Disponível em: <https://g1.globo.com/mg/triangulo-mineiro/concursos-e-emprego/ noticia/mais-de-57-dos-trabalhadores-de-uberlandia-ganhavam-ate-dois-salariosminimos-aponta-pesquisa.ghtml>. Acesso em: 4 dez. 2020.

ALVES, Giovanni. Juventude e nova precariedade salarial no Brasil: elementos da condição proletária no século XXI. In: ; ESTANQUE, Elisio (Org.). Trabalho, Juventude e Precariedade: Brasil e Portugal. Bauru: Canal 6, 2012. p. 11-32.

CARDOSO, Adalberto. Juventudes desnorteadas e geraçóes perdidas: dinâmicas do mercado de trabalho brasileiro. In: ALVES, Giovanni; ESTANQUE, Elisio (Org.). Trabalho, juventude e precariedade: Brasil e Portugal. Bauru: Canal 6, 2012. p. 65-98. 
DAYRELL, Juarez Tarcísio. A música entra em cena: o rap e o funk na socialização da juventude em Belo Horizonte. Tese (Doutorado em Educação) - USP, São Paulo, SP, 2001.

Juventude, grupos culturais e sociabilidade. JOVENes: Revista de Estudios Sobre Juventud, México, v. 9, n. 22, p. 296-313, jan./jun. 2005.

. A escola "faz" as juventudes? Reflexôes em torno da socialização juvenil. Educação e Sociedade, Campinas, v. 28, n. 100, p. 1105-1128, out 2007.

DE SORDI, Denise Nunes; MORAIS, Sérgio Paulo. FÁVERO, Douglas Gonsalves. "A gente quer pagar o que é nosso": agência e economia moral na trajetória de trabalhadores em ocupaçóes urbanas. In: BOSI, Antonio de Pádua; SOUZA, Aparecida Darc de; MORAIS, Sérgio Paulo (Org.). E. P. Thompson: história, educação e presença. São Paulo: Verona, 2018. p. 205-233.

ENGELS, Friedrich. Sobre o papel do trabalho na transformação do macaco em homem. In: ANTUNES, Ricardo (Org.). A dialética do trabalho: escritos de Marx e Engels. Sáo Paulo: Expressão Popular, 2004.

FERNANDES, Florestan. A revolução burguesa no Brasil: Ensaio de interpretação sociológica. 5. ed. São Paulo: Globo, 2005.

GRAMSCI, Antonio. Cadernos do Cárcere. 4. ed. Rio de Janeiro: Civilização Brasileira, 2006a. (v. 1: Introdução ao estudo da filosofia. A filosofia de Benedetto Croce).

GRAMSCI, Antonio. Cadernos do Cárcere. 4. ed. Rio de Janeiro: Civilização Brasileira, 2006b. (v. 2: Os intelectuais. O princípio educativo. Jornalismo).

HOGGART, Richard. "Nós" e "eles". In: . Utilizaçôes da cultura 1: Aspectos da vida cultural da classe trabalhadora. Lisboa: Editorial Presença, 1973. p. 87-122.

KHOURY, Yara Aun. Do mundo do trabalho ao mundo dos trabalhadores. In: PORTELLI, Alessandro et al. (Org.). Mundo dos trabalhadores, lutas e projetos: temas e perspectivas de investigação na historiografia contemporânea. Cascavel: Edunioeste, 2009, p. 123-140.

LOPES, José Sérgio Leite. Uma teatralização tradicional da dominação industrial. In: ARAÚJO, Angela Maria Carneiro (Org.). Trabalho, cultura e cidadania: um balanço da história social brasileira. São Paulo: Scritta, 1997. p. 177-199.

MARINI, Ruy Mauro. Dialética da dependência. In: TRASPADINNI, Roberta; STEDILE, João Pedro (Org.). Ruy Mauro Marini: vida e obra. 2. ed. São Paulo: Expressão Popular, 2011. p. 131-173. 
MARX, Karl. Grundrisse: manuscritos econômicos de 1857-1858. Sáo Paulo: Boitempo; Rio de Janeiro: Ed. UFRJ, 2011.

- O Capital. Crítica da Economia Política. Livro 1: O Processo de Produçấo do Capital. 2. ed. São Paulo: Boitempo, 2017.

PORTELLI, Alessandro. A filosofia e os fatos: narração, interpretação e significado nas memórias e nas fontes orais. Tempo, Rio de Janeiro, v. 1, n. 2, p. 59-72, 1996. fev. 1997.

O que faz a história oral diferente. Projeto História, São Paulo, v. 14, p. 25-39,

. O massacre de Civitella Val di Chiana (Toscana: 29 de junho de 1944): mito, política, luta e senso comum. In: AMADO, Janaína; FERREIRA, Marieta de Moraes (Org.) Usos \& Abusos da História Oral. 8 ed. Rio de Janeiro: Editora FGV, 2006. p. 103-130.

SPOSITO, Marilia Pontes. (Des)encontros entre os jovens e a escola. In: FRIGOTTO, Gaudêncio; CIAVATTA, Maria (Org.). Ensino médio: ciência, cultura e trabalho. Brasília: MEC/SEMTEC, 2004. p. 73-92.

THOMPSON, Edward Palmer. A miséria da teoria ou um planetário de erros: uma crítica ao pensamento de Althusser. Rio de Janeiro: Zahar, 1981.

. A formação da classe operária inglesa. 2. ed. São Paulo: Paz e Terra, 2012a. (v. 2: A maldição de Adão)

As peculiaridades dos ingleses e outros artigos. Campinas: Editora da Unicamp, $2012 b$.

VÁZQUEZ, Adolfo Sánchez. Filosofia da práxis. Buenos Aires: CLACSO; São Paulo: Expressão Popular, 2007.

WILLIAMS, Raymond. Marxismo e Literatura. Rio de Janeiro: Zahar, 1979.

2007. Palavras-chave: um vocabulário de cultura e sociedade. São Paulo: Boitempo,

WILLIS, Paul. Aprendendo a ser trabalhador: escola, resistência e reprodução social. Porto Alegre: Artes Médicas, 1991.

WOOD, Ellen Meiksins. Democracia contra capitalismo e a renovação do materialismo histórico. São Paulo: Boitempo, 2006. 


\section{Fontes orais}

ALEXANDRA [15 anos]. [nov. 2015]. Entrevistador: Douglas Gonsalves Fávero. Uberlândia, MG, 2 nov. 2015.

ANTÔNIO [20 anos]. [nov. 2015]. Entrevistador: Douglas Gonsalves Fávero. Uberlândia, MG, 5 nov. 2015.

EDUARDO [15 anos]. [nov. 2015]. Entrevistador: Douglas Gonsalves Fávero. Uberlândia, MG, 5 nov. 2015.

ERNESTO [22 anos]. [nov. 2015]. Entrevistador: Douglas Gonsalves Fávero. Uberlândia, MG, 3 nov. 2015.

PATRÍCIA [20 anos]. [nov. 2015]. Entrevistador: Douglas Gonsalves Fávero. Uberlândia, MG, 11 nov. 2015.

ROSA [27 anos]. [nov. 2015]. Entrevistador: Douglas Gonsalves Fávero. Uberlândia, MG, 10 nov. 2015.

TITO [27 anos]. [nov. 2015]. Entrevistador: Douglas Gonsalves Fávero. Uberlândia, MG, 9 nov. 2015.

Resumo: O presente artigo aborda as relaçōes de trabalho vividas por jovens de uma ocupação urbana em Uberlândia (MG). Assim, apresentamos - por meio da História Oral como uma metodologia de pesquisa que permite adentrar na experiência social - os limites objetivos e as pressōes sociais, morais e culturais que as relaçōes de trabalho exercem sobre esses jovens. Como determinaçôes estruturantes da vida social, o artigo apresenta o trabalho com as relaçóes de moradia, reprodução do núcleo familiar, sociabilidade e estilo. Em seguida, abordamos as relaçóes de classe, expectativas e as pressóes morais em torno do trabalho, perpassando pelas dimensões da educação formal e ascensão social, assim como a noção de trabalhador em contraponto a visão de criminosos e invasores de propriedade que as condiçóes de periferia e ocupação respectivamente impóem.

Palavras-chave: Trabalho. Experiência. Determinaçôes. Modos de vida. Ocupação urbana.

\section{Oral History and working youth in the periphery: limits, pressures and expectations}

Abstract: This paper discusses the labor relations experienced by young people from an urban occupation in Uberlândia (MG). Thus, we present - through Oral History as a research methodology that allows us to enter the social experience - the objective limits and social, moral and cultural pressures that work relationships exert on these young people. As structural determinations of social life, the paper presents the work with the housing, 
reproduction of the family nucleus, sociability and style relations. Then, we approach class relations, the expectations and moral pressures around work, going through the dimensions of formal education and social ascension, as well as the notion of worker in contrast to the view of criminals and property invaders that the conditions of periphery and occupation respectively impose.

Keywords: Work. Experience. Determinations. Ways of life. Urban occupation.

Recebido em 10/08/20

Aprovado em 03/11/20 